\title{
NEW METHODOLOGICAL APPROACH TO THE STUDY AND ASSESSMENT OF THE IMPACT OF SOCIO-ECONOMIC ENVIRONMENT ON THE ACADEMIC GIFTEDNESS OF RUSSIAN STUDENTS
}

\author{
Natalia Borscheva, Yulia Fedorova, Egor Fedorov and Guzal Islamova \\ I.M. Sechenov First Moscow State Medical University (Sechenovskiy Univertsity), \\ 8/2 Trubetskaya Street, Moscow, Russia
}

\begin{abstract}
The article proposes a new methodological approach to the study and assessment of the impact of socio-economic environment on the academic giftedness of Russian students. The assessment of factors of the social and economic environment is carried out, the correlation model is constructed, the key factors influencing academic giftedness of school students are revealed. A regression model reflecting the influence of socio-economic factors on the academic giftedness of Russian schoolchildren in the dynamics from 2000 to 2018 is constructed. Based on the obtained scientific data, Forecast of the development of academic giftedness of schoolchildren, under the influence of social environment factors.
\end{abstract}

Keywords: factors of socio-economic environment; academic giftedness; external environment; education

Cite this Article: Natalia Borscheva, Yulia Fedorova, Egor Fedorov and Guzal Islamova, New Methodological Approach to the Study and Assessment of the Impact of Socio-Economic Environment on the Academic Giftedness of Russian Students, International Journal of Civil Engineering and Technology, 11(10), 2020, pp. 1-8. https://iaeme.com/Home/issue/IJCIET?Volume $=11 \&$ Issue $=10$

\section{INTRODUCTION}

Creating conditions that ensure the identification and development of gifted children, the realization of their potential, is one of the priorities of modern society. Giftedness is a systemic, life-developing quality of the psyche that determines whether a person can achieve higher, extraordinary results in one or more activities compared to other people. Today, most psychologists recognize that the level, qualitative originality and character of the development of giftedness is always the result of a complex interaction of heredity (natural inclinations) 
and the social environment, mediated by the activities of the child (game, educational, labor). In this case, of particular importance are the child's own activity, as well as psychological mechanisms of self-development of the individual, underlying the formation and implementation of individual talent (Bogoyavlenskaya D., 2019), (Mendaglio S., 2019), (Miklyaeva A.V., 2019), (Petrova S.O., 2019).

Under the giftedness of the child understand a higher than his peers' susceptibility to learning and more pronounced creative manifestations (Almukhambetova A., HernándezTorrano, D, 2020), (Gürlen E.,2019). Giftedness as a system of education of the individual is a coordinator, regulator, stimulator of creative activity, contributes to finding solutions that enable the child to better adapt to the world, the environment, other people, himself. Giftedthis is the most promising group of students, which can not be approached with standard measures, as their training in traditional methods destroys creativity (de Oliveira A.P, 2020) (Ottone-Cross K.L.,2019). The most complete disclosure of the potential of gifted and talented children is an urgent task of modern education. Giftedness is distinguished by the breadth of manifestation and type of preferred activity. One of the types of giftedness is intellectual giftedness-the ability to think, analyze, compare facts. Highly gifted children, defined mainly by intelligence tests, make up a very small proportion of the population. The coefficient of mental development of such children is 160-200 points. In some studies, it is assumed to refer to the highly gifted those whose IQ 160-179 points, and to the exceptionally gifted those who have it 180 and above (Pereira Da Costa M., 2019).

A different kind of talent - leadership or social ability. Studies have shown that this type of giftedness requires above-average mental development. There are many definitions of leadership talent, which can be identified common features. The main thing is that it is a certain set of skills of the leader which is necessary for achievement of the purposes decided before. By definition, leadership skills are mostly interpersonal and include flexibility, openness, organizational skills. Leadership requires such personal traits as self-esteem, emotional development, and high moral qualities. Another kind of talent - artistic talent. This kind of giftedness is maintained and developed in special schools, clubs, studios. It implies high achievements in the field of artistic creativity and performing skills in music, painting, sculpture, acting. But one of the major problems is that the school recognizes and respects these abilities.

Musical giftedness is a kind of giftedness that is characterized by the highest and extremely individual manifestation of musical abilities. Indicators of musical talent are brilliant ear for music, phenomenal memory, plastic and well-coordinated motor "apparatus", incredible learning and high performance. We will not dwell on the above types of giftedness. In our study, we will try to assess the impact of the socio-cultural environment on this type of giftedness as academic giftedness.

Academic giftedness is a pronounced ability to learn. This talent is manifested in the successful teaching of individual subjects and is considered more private, selective. In this type of giftedness has a fairly high intelligence, but the foreground is a special ability to learn. Students of this type of giftedness, first of all, are able to brilliantly assimilate information, that is, to learn. Features of their cognitive sphere (thinking, memory, attention), some features of their motivation are such that make the teaching for them easy enough, and in some cases even enjoyable. Students, who are called the pride of the school, often belong to this type of giftedness, which should not be underestimated. It is from these students that wonderful professionals, real masters of their craft, are subsequently obtained.

The academic type of giftedness has its own subspecies: 1) schoolchildren with a broad ability to learn - they easily master any activity, show noticeable success in all school 
Sciences, 2) schoolchildren who have increased ability to learn are manifested only in one or more close areas of activity (to the exact or, for example, humanities).

The difference between intellectually and academically gifted children is that intellectuals are necessarily independent in thinking - critical, have a need for understanding and comprehension of the world, the ability to independently reach a global, philosophical understanding of complex intellectual problems. And academically gifted students are always geniuses of teaching, they are some kind of brilliant professionals of school and then student work, excellent masters of fast, durable and high-quality assimilation. Academic giftedness is more adaptive, their intelligence serves them to adapt and meet the requirements of the social environment.

One of the most controversial issues concerning the problem of gifted children is the frequency of children's giftedness. There are two extreme points of view: all children are gifted - gifted children are extremely rare. Supporters of one of them believe that almost any healthy child can be developed to the level of the gifted, provided that favorable conditions are created. For others, giftedness is a unique phenomenon, in which case the focus is on finding gifted children, but the influence of the socio-cultural environment is not denied.

According to various studies in Russia today from 1-6 percent of gifted children, while in Japan 13\%, in the US-25\% (International PISA studies, 2018). The problem of identifying, developing and supporting gifted children in Russian society is very acute. Many experts argue that it is possible to develop academic giftedness if favorable external conditions are created. However, there is no consensus on this issue.

\subsection{Purpose of Research}

The aim of the study is to assess the impact of the social environment on the development of academic giftedness of schoolchildren in Russia.

\subsection{Research Problem}

1. Determine the number of gifted students (academic giftedness) in Russia.

2. To collect statistical data on several groups of factors (social, demographic, economic groups of factors) of the social environment that have a possible impact on the academic giftedness of schoolchildren.

3. Build a correlation model, identify the factors that have the greatest impact on the development of academic giftedness of students.

4. Build a regression model.

\subsection{The hypothesis of Scientific Research}

The development of academic talent of Russian schoolchildren is greatly influenced by the social environment. Factors of the social environment can have both positive and negative impact on the academic giftedness of schoolchildren.

\section{METHODS OF RESEARCH}

Giftedness is a complex, multidimensional concept. There are many definitions of giftedness. By giftedness we mean " a qualitatively peculiar combination of abilities, on which the possibility of achieving high results in the performance of a particular activity depends. This is a system, developing during the life quality of the psyche, which determines the possibility of achieving higher (unusual, extraordinary) results" (Burkatskaya N., 2012). Giftedness consists of many components, including genetic and social. Theoretical studies of foreign and Russian scientists (N. S. Leites, A. M. Matyushkin, B. Clark, J. Repzulli, S. Reese, N. 
New Methodological Approach to the Study and Assessment of the Impact of Socio-Economic Environment on the Academic Giftedness of Russian Students

Burkatskaya etc.) define giftedness as an innate anatomical and physiological feature of the nervous system (makings), which develops in the process of specially organized activities and can manifest itself in different age periods of childhood (Burkatskaya N., 2012), (Renzulli J, 1997), (Leites N. S., 2000).

Today, the majority of studies aimed at the identification and development of gifted children. In school practice, quite often limited to the assessment of intelligence quotient (IQ), which is determined by psychometric intelligence tests. It is these tests (often together with creativity tests used to measure creativity) that are most often used in the selection of children for classes and schools for the gifted. This ignores the fact that the use of intelligence and creativity tests has a number of limitations. First, most intelligence tests are not designed to detect intellectual giftedness, but for other purposes. The intelligent Wexler scale for children (the original version of the WISC, as well as its domestic modifications) was intended to determine the level of General intelligence (in particular, to identify delays in mental development), The amthauer intelligence structure test (SIT) - for career guidance and professional selection, the differential ability test - DAT) - for predicting academic performance, etc. Only some of the tests provided for the evaluation of the highest possible results: the culturally free Kettell test (CFT-C) and the Raven Progressive matrices test (aPMR).

It should also be borne in mind that the test data are highly dependent on the testing situation, the emotional state of the child. At the same time, the more gifted a child is, the greater this dependence is. Therefore, psychometric tests do not predict the level of achievement of gifted children. Many intelligence tests measure a specific (private) intellectual ability, i.e. the formation of specific mental operations. Thus, the existing psychometric tests of intelligence, fixing its components, do not affect the links between them, do not evaluate the system of its manifestation. Thus, psychometric tests can be used as one of the many sources of additional information in the evaluation of a gifted child.

Today, the Federal target program "Gifted children" has developed a "working concept of giftedness". In this concept, the leading domestic experts in the field of psychology of giftedness believe that taking into account the specifics of giftedness in childhood, the most adequate form of identification of signs of giftedness of the child is psychological and pedagogical monitoring. Pihologo-pedagogical monitoring, used to identify gifted children, must meet a number of requirements, including "the identification of signs of giftedness of the child not only in relation to the actual level of his mental development, but also taking into account the zone of proximal development (in particular, in conditions of enriched subject and educational environment in the development of individualized learning strategy of the child)"(Education in RussiaRussian. Federal State Statistics Service, 2020) in the context of changes in the external social environment.

This research was conducted using statistical data of the Federal state statistics service, official data of the Federal Treasury, official data of the Federal service for supervision of education and science (Rosobrnadzor), as well as using statistical and economic and mathematical methods (Education in RussiaRussian. Russian Federal State Statistics Service, 2020).

To determine the number of gifted students in Russia, we used the official data of the Federal service for supervision of education and science (Rosobrnadzor)in the dynamics from 2000 to 2018 (Education in RussiaRussian. Russian Federal State Statistics Service, 2020). Academically gifted students are students who achieve high success in learning, internally motivated to cognitive activity. 
The indicator "Academic giftedness of schoolchildren" is calculated as the ratio of the total number of students who received 100 points in one of the subjects on the Unified state examination, to the total number of exam participants in a given academic year (Table 1).

Comments to the table are presented below the table 1 .

Table 1 Academic giftedness of schoolchildren

\begin{tabular}{|c|c|c|c|c|}
\hline $\begin{array}{c}\text { S } \\
\text { No }\end{array}$ & Year & $\begin{array}{c}\text { The total number of } \\
\text { participants of the unified state } \\
\text { exam, people. }\end{array}$ & $\begin{array}{c}\text { The number of students } \\
\text { who received the } \\
\text { maximum number of } \\
\text { points (100 points), people. }\end{array}$ & $\begin{array}{c}\text { Gifted schoolchildren (academic } \\
\text { ability) to the total number of } \\
\text { students, \% }\end{array}$ \\
\hline 1 & 2010 & 877246 & 2884 & $0,33 \%$ \\
\hline 2 & 2011 & 760618 & 2887 & $0,38 \%$ \\
\hline 3 & 2012 & 843766 & 3535 & $0,42 \%$ \\
\hline 4 & 2013 & 754776 & 9504 & $1,26 \%$ \\
\hline 5 & 2014 & 754303 & 3484 & $0,46 \%$ \\
\hline 6 & 2015 & 725000 & 4608 & $0,64 \%$ \\
\hline 7 & 2016 & 750000 & 5009 & $0,67 \%$ \\
\hline 8 & 2017 & 703000 & 5026 & $0,71 \%$ \\
\hline 99 & 2018 & 731000 & 6136 & $0,84 \%$ \\
\hline
\end{tabular}

Source: Russian Federal State Statistics Service

We have calculated the percentage of gifted students (academic giftedness) in the dynamics as the ratio of the total number of students who received 100 points in all subjects on a Single state exam to the total number of participants in the exam this year in the dynamics from 2000 to 2018 .

The study collected statistical data on the factors of the social environment, which has a direct impact on the development of giftedness. The higher the standard of living, the more economically developed the society, the higher the level of education and the more adults participate in continuous education and development, the better the social and living conditions, the higher the state spending on education, the more opportunities for the development of gifted children.

\section{RESULTS AND DISCUSSION}

The purpose of this study is to identify environmental factors that affect the development of academic giftedness of Russian schoolchildren. This research will be useful for developing strategic directions for further development of the education system. Correlation and regression analysis was used to determine the key macro factors that affect the development of academic giftedness of Russian schoolchildren in the conditions of the macroeconomic environment. Its task was to assess the degree and direction of influence of environmental factors on the development of academically gifted students. In the course of this research, political, economic, social, demographic, technological, and other factors that influence the development of academic giftedness were identified.

Overall, there were about 42 macro factors. Data were obtained from publicly available electronic sources. (Indicators of education, 2018), (Education in RussiaRussian. Federal State Statistics Service, 2018), (Statistics of Russian education, 2020), (Federal service state statistics, 2020), (Gorodnikova, N. 2017).

The correlation analysis revealed the closest relationship of the resulting indicator (the number of gifted students to the total number of students, \%) with three external factors (x1, $\mathrm{x} 2, \mathrm{X} 3$ ), which are presented in table 2 . In the course of correlation analysis, a large number of external factors (42 factors) were used in dynamics from 2010 to 2018. The explanation is 
as follows: to select macro factors for further research, the greatest pair correlation between them and the resulting indicator criterion was determined.

As a result, the indicator "academic giftedness" was selected, which characterizes the number of gifted students who received the maximum number of points on the unified state exam (100 points) to the total number of students, \%). In the course of the analysis, some methodological prerequisites that are significant for interpretation were considered. So, a correlation and regression analysis was performedDuring the study, a correlation model was built. 42 factors of the social environment in the dynamics from 2000 to 2018 were used in the construction of the correlation model. The result was the indicator "Gifted students (academic giftedness) to the total number of students, \%".

In the constructed correlation model revealed a close correlation between the resulting indicator and factors such as:

" Average monthly nominal accrued wages of employees, rubles. "correlation coefficient 0.9;

" Public spending on education, billion rubles. "correlation coefficient 0.8;

" the Volume of innovative goods and services produced in Russia " correlation coefficient 0.9 .

Statistical data for the regression model is presented in table 2.

Comments to the table are presented below the table 2 .

Table 2 Statistical data for building a regression model

\begin{tabular}{|c|c|c|c|c|c|}
\hline $\begin{array}{c}\text { S. } \\
\text { No }\end{array}$ & Year & $\begin{array}{c}\text { Gifted schoolchild } \\
\text { (academic } \\
\text { giftedness) to the } \\
\text { total number of } \\
\text { schoolchildren, \% } \\
\mathbf{( y )}\end{array}$ & $\begin{array}{c}\text { Average } \\
\text { monthly } \\
\text { nominal } \\
\text { accrued } \\
\text { wages of } \\
\text { employees, } \\
\text { rub. } \\
\mathbf{( x 1 )}\end{array}$ & $\begin{array}{c}\text { Government } \\
\text { expenditure on } \\
\text { education, billion } \\
\text { rub. } \\
\text { (x2) }\end{array}$ & $\begin{array}{c}\text { Volume of } \\
\text { innovative goods } \\
\text { (services) produced } \\
\text { in Russia, mln. rub. } \\
\text { (x3) }\end{array}$ \\
\hline 1 & 2010 & 0.3 & 28027 & 1893.9 & 25794618.1 \\
\hline 2 & 2011 & 0.38 & 32809 & 2231.8 & 33407033.4 \\
\hline 3 & 2012 & 0.42 & 36450 & 2588.4 & 35944433.7 \\
\hline 4 & 2013 & 0.30 & 39648 & 2888.8 & 38334530.2 \\
\hline 5 & 2014 & 0.46 & 42136 & 3037.3 & 41233490.9 \\
\hline 6 & 2015 & 0.64 & 43408 & 3034.6 & 45525133.8 \\
\hline 7 & 2016 & 0.67 & 47554 & 3103.1 & 51316283.50 \\
\hline 8 & 2017 & 0.71 & 51197 & 3264 & 57611057.8 \\
\hline 9 & 2018 & 0.84 & 55569 & 3348 & 59344811.00 \\
\hline 10 & Correlation coefficient (R) & 0.9 & 0.8 & 0.9 \\
\hline
\end{tabular}

Source: Russian Federal State Statistics Service

On the basis of the data obtained, we can observe the positive impact of all three identified factors of the social environment on the development of academic giftedness of schoolchildren.

To confirm the influence of the identified factors on the resulting indicator, we have built a regression model (1)

$$
\mathrm{y}=0.034+1.166 \mathrm{x} 1+0.03 \times 2+1.715 \times 3(1)
$$

where $\mathrm{x} 1$ - average monthly nominal accrued wages of employees, rub. 
x2- government expenditure on education, billion rub.

x3 - volume of innovative goods (services) produced in Russia, mln.rub.

The resulting relationship can be explained as follows: the growth of family income opens up additional opportunities for the development of children, the opportunity to visit sections, clubs, museums, cultural events, which has a positive impact on the development of giftedness. The increase in public spending on education, equipping schools with modern laboratory and computer classes, material incentives for students to participate and win the Olympics, the creation of educational centers to identify, develop and support gifted children (educational center "Sirius") also has a positive impact on the increase in the number of gifted students. The influence of the third factor "the Volume of innovative goods and services produced in Russia" can be explained by the fact that innovation is based on the idea, creativity and innovation. Parents with creativity teach their children to find original solutions to non-standard problems, to find non-standard solutions to difficult situations. One of the characteristics of the personality of gifted children is the ability to produce original ideas.

To make a forecast of the development of academic giftedness of Russian schoolchildren under the influence of the identified factors of the social environment, we used the values obtained when constructing trends of these factors by substituting them into the resulting regression model. Thus, in 2025, the indicator "Academically gifted schoolchildren" in Russia will reach a value of $2.65 \%$. The forecast is built using a regression model and based on the trends of the identified social environment factors (fig.1).

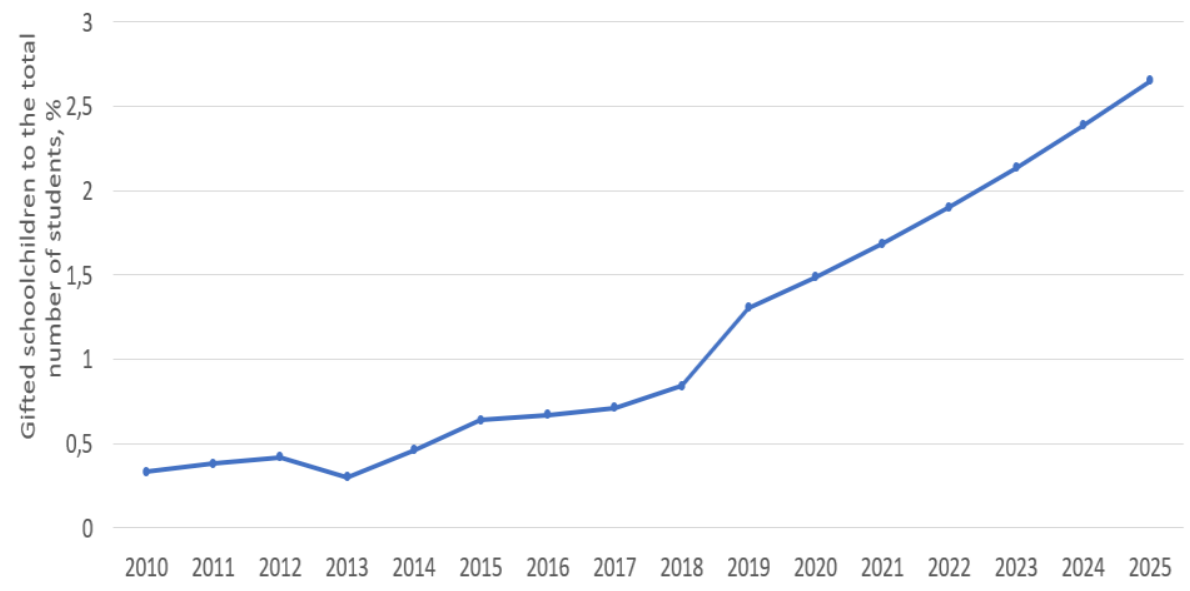

Figure 1 Forecast of the development of academic giftedness of schoolchildren, under the influence of social environment factors

Source: Russian Federal State Statistics Service

\section{CONCLUSION}

As a result of research, the correlation model is constructed and the factors having the greatest positive influence on development of academic giftedness of school students in Russia are revealed. The regression model shows the dependence of the number of gifted students in Russia on changes in the factors of the social environment. As a result of the study, the hypothesis was confirmed by practical results. The results can be used in the development of government measures to support gifted students in Russia, creating conditions for the identification, development and support of gifted children in the family and at school. 
New Methodological Approach to the Study and Assessment of the Impact of Socio-Economic Environment on the Academic Giftedness of Russian Students

\section{REFERENCES}

[1] Bogoyavlenskaya D. BPhilosophical fundamentals of the theory of giftedness // CulturalHistorical Psychology. Volume 15, Issue 2, 2019, Pages 14-21.

[2] Mendaglio S., Kettler T., Rinn A. Psychology of Giftedness and the Theory of Positive Disintegration: A Conversation with Sal Mendaglio // Journal of Advanced Academics. Volume 30, Issue 4, 2019, Pages 500-507.

[3] Miklyaeva A.V., Khoroshikh V.V., Volkova E.N. Subjective factors of gifted adolescents' psychological well-being: A theoretical model // Science for Education Today.Volume 9, Issue 4, 2019, Pages 36-55.

[4] Petrova S.O. Methodology and methods of studying giftedness in contemporary Russian psychological studies // Voprosy Psikhologii. Volume 2019-January, Issue 4, 2019, Pages 7888

[5] Almukhambetova A., Hernández-Torrano, D. Gifted Students' Adjustment and Underachievement in University: An Exploration From the Self-Determination Theory Perspective // Gifted Child Quarterly. Volume 64, Issue 2, 1 April 2020, Pages 117-131.

[6] Gürlen E., Özdiyar Ö., Şen, Z. Social network analysis of academic studies on gifted people // Egitim ve Bilim. Volume 44, Issue 197, 2019, Pages 185-208.

[7] de Oliveira, A.P, Capellini V.L.M.F., Rodrigues, O.M.P.R High abilities/giftedness: Social skills intervention with students, parents/guardians and teachers // Revista Brasileira de Educacao Especial. Volume 26, Issue 1, January-March 2020, Pages 103-118.

[8] Ottone-Cross, K.L., Gelbar N.W., Dulong-Langley S., Root M.M., Avitia M.J, Bray M.A., Courville T., Pan, X. Gifted and learning-disabled: A study of strengths and weaknesses in higher-order processing // International Journal of School and Educational Psychology. Volume 7, Issue sup1, 20 December 2019, Pages 173-181.

[9] Pereira Da Costa M. Theories of intelligence: Conceptions and measures of giftedness // Neuropsychiatrie de l'Enfance et de l'Adolescence. Volume 67, Issue 3, May 2019, Pages 152157.

[10] International PISA studies. Electronic resource. https://rosuchebnik.ru

[11] Burkatskaya N. In. Gifted children in secondary school, 2012. Electronic resource. http://ext.spb.ru

[12] Renzulli J. Model of enriched schooling.Basic concepts of giftedness and creativity, 1997.

[13] Babaeva Y.D., Leites N. S., Maryutina A.M. Psychology of giftedness of children and adolescents: educational settlement for children. and environments, 2000.

[14] Education in RussiaRussian. Federal State Statistics Service, 2018. Electronic resource. https://www.gks.ru/folder/13398

[15] Indicators of education: 2018: statistical collection / N. In. Bondarenko, L. Gokhberg, N. In. Kovaleva and others; NAT. research. University "Higher school of Economics". - Moscow: HSE, 2018.

[16] Statistics of Russian education. Electronic resource http://stat.edu.ru/

[17] Federal service state statistics. Electronic resource. https://www.gks.ru/

[18] Gorodnikova, N. 2017. Indicators of innovation statistical yearbook Higher School of Economics. Moscow: Published Higher School of Economics. 